\title{
Estimates of suspended solid transport in the Pará River Estuary
}

\author{
Adriel Guimarães Carneiro ${ }^{1 *(-)}$, Yuri Onça Prestes ${ }^{1 \oplus}$, Marcelo Rollnic $^{1[}$ \\ 1 Universidade Federal do Pará, Laboratório de Pesquisa em Monitoramento Ambiental Marinho - Belém - Pará - Brazil \\ *Corresponding author: adrielcarneiro1@gmail.com
}

\section{Abstract}

The aim of the present study was to quantify the suspended solid concentrations $\left(\mathrm{C}_{\mathrm{SSL}}\right)$ and suspended solid transport $\left(T_{\text {SSL }}\right)$ in the mixing zone of the Pará River Estuary. This estuary is located at the southeastern extreme of the estuarine complex of the Amazon River, and receives input from Tocantins and Pará rivers and other local tributaries, with a total discharge of approximately $10^{4} \mathrm{~m}^{3} \mathrm{~s}^{-1}$. Two field campaigns were conducted to collect samples of Suspended Particulate Matter (SPM) and measure turbidity. Bottom and surface samples were collected hourly throughout a semidiurnal tidal cycle at two points in the estuary (Left Margin [LM]: $-0.7287^{\circ}-48.2408^{\circ}$ and Right Margin [RM]: $-0.6051^{\circ}-48.4048^{\circ}$ ) in both the dry and rainy seasons. The TSSL was determined using a linear correlation between SPM and turbidity. The results indicate that both the RM and LM points were export routes of suspended solids to the adjacent ocean. However, both lateral and seasonal differences were observed in the PRE samples, with the RM point exporting more suspended solids to the adjacent ocean than the LM point. The TSSL was higher in near-bottom layers on the RM, and the lutocline was broader in comparison with the LM. The correlation between the CSSL at the bottom and in the water column was higher on the LM, and indicated that approximately $80 \%$ of the CSSL on this margin derives from resuspension. The sum of the evidence indicates that both points export suspended solids to the ocean.

Descriptors: Suspended particulate matter, Turbidity, Linear regression, Lutocline, Resuspension.

\section{INTRODUCTION}

Estuaries are transitional, coastal bodies of water inserted between continental and marine environments. All the physical processes that occur in this environment, such as circulation, mixing and stratification, are under the influence of numerous variables, such as freshwater discharge, tidal forces, salinity, circulation in the adjacent oceanic region, and direct or remote wind action (Cameron and Pritchard, 1963; Pritchard, 1967; Miranda, 2012). Geomorphology, freshwater input, and tides are also the principal determinant of salinity gradients and circulation in estuaries (Hansen and Rattray, 1966).

Submitted on: 26/August/2019

Approved on: 10/April/2020

Associate Editor: Eduardo Siegle

Editor: Rubens M. Lopes

(i) 2020 The authors. This is an open access article distributed under the terms of the Creative Commons license.
In estuarine environments, the concentrations of suspended matter are generally high, and particles tend to be fine, cohesive, and prone to flocculating, as well as rich in organic matter (Dyer, 1997). There are countless natural and anthropogenic factors that influence the suspension of particles in estuaries, such as wind forces and freshwater discharge, as well as coastal erosion, rain, substrate dredging and fisheries (Paphitis and Collins, 2005). The intensity of these factors determines the concentration of solids transported in suspension. In addition, given the dynamic nature of most estuaries, the concentrations of sediments transported by dragging, saltation and/or suspension can vary considerably between adjacent estuaries or even within an estuarine system over time (Dyer, 1994; Uncles, 2002).

In this context, any study of suspended load will typically focus on one or more of the following aspects: (i) the amount of suspended matter per volume of 
water; (ii) the total amount of transported matter over a given time interval, and (iii) the size of the particles transported in suspension (Wood, 1977). In the present case, the fact that the study area is located in the Amazon region should also be taken into account, given that the estuaries in this region are more than usually complex and dynamic, with extremes of freshwater discharge and sediment load, well-defined seasonality, and major tidal forces (Aveline, 1980). This implies that the three traditional points of focus will need to be modified to support a more reliable analysis of estuarine systems in the Amazon region.

Many studies of suspended matter have focused on the relationship between the dynamics and processes of an estuary (Postma, 1967; Schubel, 1971; Allen et al., 1980; Nichols, 1984; Hunt and Lemckert, 2000; Vinzon and Mehta, 2001; Winterwerp, 2011; Uncles and Monismith, 2011). In the case of tropical estuaries, however, studies of the dynamics of suspended matter in the system are more restricted due to a number of factors, in particular, the difficulty of obtaining synoptic measurements in these environments (Gabioux et al., 2005; Siegle et al., 2009; Schettini et al., 2010; Schettini et al., 2013). In tide-dominated tropical estuaries, then, such as the one that is the subject of the present study, the extension of the area and the magnitude of its physical processes are a major challenge for the reliable analysis of flux and transport processes.

A number of previous studies (Corrêa, 2005; Costa, 2014; Latrubesse and Stevaux, 2002; Prestes et al., 2020) have focused on the area of the Pará River Estuary (PRE - the subject of the present study), analyzing the dynamics of this system, and relating the concentrations of suspended solids with its geomorphology. These studies highlighted the importance of consolidating a database for this estuary, given the relevance of this system, not only for its immediate environment, but also for much of the surrounding area.

The discharge of the PRE $\left(10^{4} \mathrm{~m}^{3} \mathrm{~s}^{-1}\right)$ is only an order of magnitude smaller than that of the Amazon River, at $10^{5} \mathrm{~m}^{3} \mathrm{~s}^{-1}$ (Prestes et al., 2020), and includes millions of tons of sediments from the Tocantins and Pará river systems (Costa, 2014; Latrubesse and Stevaux, 2002), resulting in the transport of an enormous amount of suspended solids to the adjacent ocean. The sheer magnitude of the PRE reinforces its importance to the surrounding region, and the need for more reliable and systematic data on its dynamics.

The estuary has considerable socio-economic value, supporting artisanal and industrial fisheries, which are among the principal source of local income, as well as intense fluvial traffic for the transportation of passengers and cargo. The ecological value of the PRE is also considerable, given its discharge of freshwater, nutrients and minerals onto the adjacent continental shelf. The margins of the PRE are also covered with large amounts of well-preserved mangrove ecosystems, which are also regulated by the estuary's transport of particulate and dissolved material, and the associated patterns of deposition and erosion (Schaeffer-Novelli et al., 1990; SchaefferNovelli et al., 2000). The PRE can thus be considered the principal route of freshwater flow and material transport in the eastern Amazon coastal zone.

In this context, the present study quantified and evaluated the Suspended Solid Concentration $\left(\mathrm{C}_{\mathrm{sSL}}\right)$ and Suspended Solid Transport $\left(\mathrm{T}_{\mathrm{SSL}}\right)$ at two points located within the mixing zone of the tidedominated PRE. Vertical profiles were analyzed to evaluate potential differences in distribution patterns within the estuary, including seasonal variation, over a semidiurnal tidal cycle, and to determine the possible import and export routes for the suspended solids transported by the estuary.

\section{MATERIAL AND METHODS}

\section{STUDY AREA}

The PRE is located in the Amazon region, where it begins to the southeast of Marajó Island, extending $300 \mathrm{~km}$ northeastward to discharge into the Atlantic Ocean, where it is $40-50 \mathrm{~km}$ wide at its mouth. The PRE does not have a source per se, but rather, accumulates the discharge of a number of tributaries, including the Tocantins and Pará Rivers, and part of the discharge of the Amazon River, through the Breves Strait (Callède et al., 2010).

The region's climate is divided into two distinct periods of rainfall. The wet season occurs between December and June, when the rains are especially intense, peaking in January and April. The remaining months of the year tend to be much drier, reaching an extreme between September and November (Moraes et al., 2005; El-Robrini et al., 2006). 
The study area is located in the Mixing Zone of the PRE, approximately $45 \mathrm{~km}$ from its mouth, an area under the influence of a semidiurnal mesotidal and macrotidal regime (Figure 1). The tidal range varies from $1.5 \mathrm{~m}$ in the innermost portions, to $5 \mathrm{~m}$ on the coast (Beardsley et al., 1995).

\section{DATA ACQUISITION}

Data were acquired during two field campaigns, one during the dry season (October 6-10th, 2014) and the other during the rainy season (June 1-4th, 2015), both on the spring tide. Data collection consisted of hourly measurements over a semidiurnal tidal cycle (13h) at a point on each margin of the estuary (Figure 1), approximately $45 \mathrm{~km}$ from its mouth.

Data acquisition was not simultaneous, with data being collected initially on the right margin (RM) and subsequently on the left margin (LM). During the first campaign, data were collected at LM approximately 4.5h after the RM, while there was a difference of $1.5 \mathrm{~h}$ during the second campaign. While the data acquisition was not simultaneous at the two points, tidal amplitude was equivalent in both campaigns, at $3.0 \mathrm{~m}$ in the dry season and $3.4 \mathrm{~m}$ in the rainy season.

To determine Suspended Particulate Matter (SPM) in each campaign, bottom and surface water samples were collected hourly at each station with a
Van Dorn bottle. Twenty-eight samples were taken at each point in the two seasonal campaigns. Turbidity was quantified in hourly profiles of the whole water column using an Infinity-turbi ATU74W-USB optical backscatter sensor with a measuring frequency of $1 \mathrm{~Hz}$. Current speed was estimated using an acoustic Doppler current profiler, with the data being collected by the Pró-Amazônia and the Amazonian Hydrology Network (RHIA) projects, simultaneously with the SPM and turbidity data, which were used to estimate sediment transport.

\section{DATA PROCESSING AND ANALYSIS}

A least-squares linear regression between SPM and turbidity, collected in situ, was used to calculate the $\mathrm{C}_{\mathrm{SLL}}$. This method consists of fitting a line to a set of points, generated by the relationship between values on the $x$ and $y$ axes (Emery and Thomson, 2014). The regression generates a first degree equation (equation 1):

$$
\begin{aligned}
C_{\mathrm{SSL}}\left(\mathrm{REO}_{\mathrm{FTU}}\right)= & 0.3974\left(\mathrm{REO}_{\mathrm{FTU}}\right)-7.065 \\
\mathrm{r}^{2} & =0.8283
\end{aligned}
$$

Where $\mathrm{x}$ is the independent variable, REO is the optical backscatter and $r^{2}$ is the equation residual or reliability index (approximately $80 \%$ ). This equation

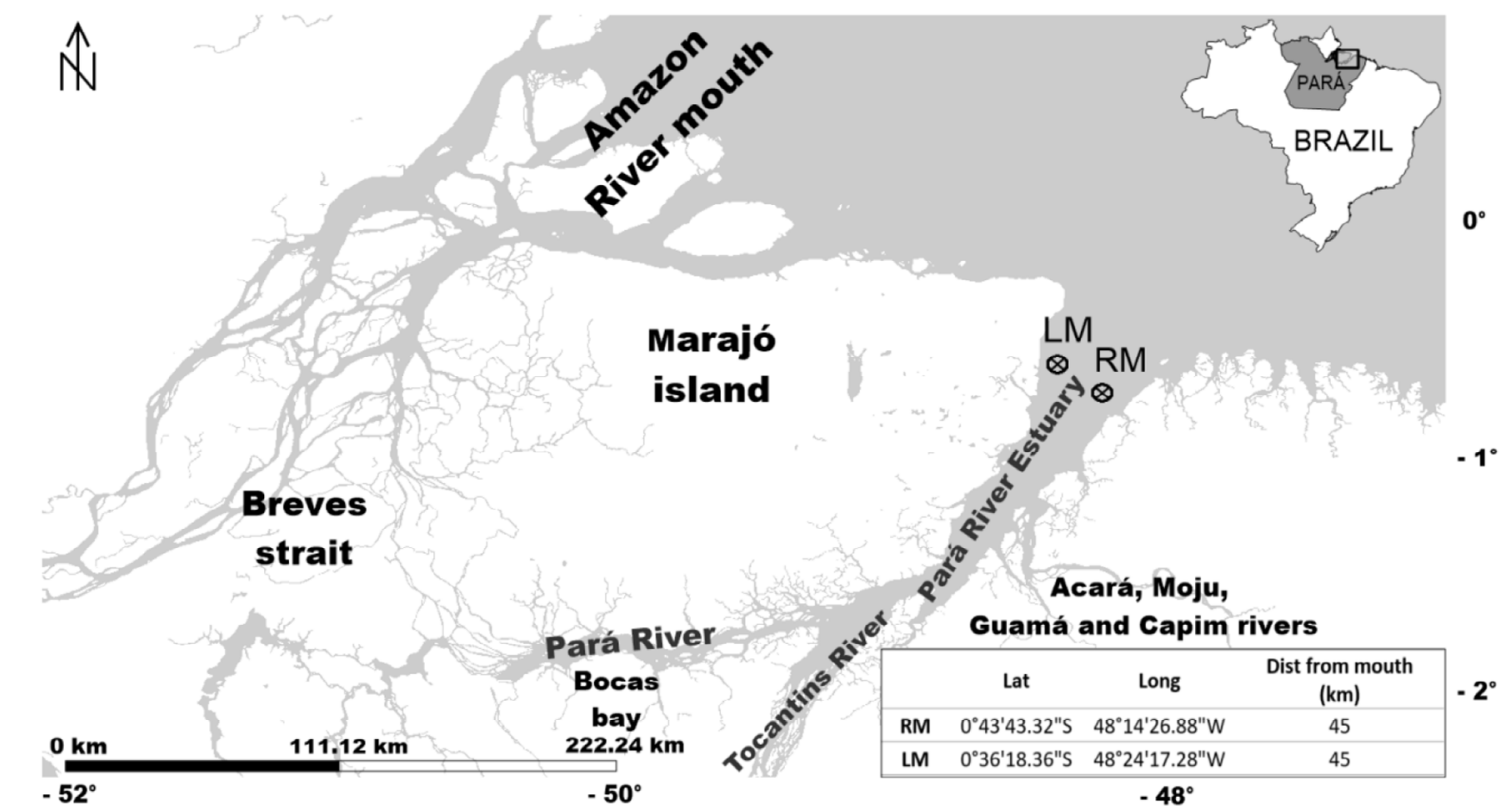

Figure 1. Map of the study area, showing the Pará River Estuary and some of its tributaries, and with the sampling points on the Right (RM) and Left (LM) margins. Source: The authors. 
was applied to the vertical turbidity profiles, as their sampling mesh is temporally and spatially more representative.

The $T_{\text {SSL }}$ was calculated based on the property flow equation for vertical profiles, described by Miranda et al. (2012) and adapted by Siegle et al. (2009). Here, the equation has been further adapted to calculate suspended solid transport $\left(\mathrm{T}_{\mathrm{SSL}}\right)$, with the term $A_{t^{\prime}}$ which refers to the area of the cross-section, being replaced by $h_{t}$, which represents the vertical height of the section. The $_{\text {SSL }}$ is thus calculated using equation 2 :

$$
F_{t}=10^{-3} \cdot u \cdot h_{t} \cdot C_{t}
$$

Where $F_{t}$ is suspended solid transport as a function of time, $10^{-3}$ is the conversion factor from gram to kilogram, $u$ is the velocity component across the water column during one semidiurnal tidal cycle, $\mathrm{h}(\mathrm{t})$ is the height of profiles, and $\mathrm{Ct}$ is the $\mathrm{C}_{\mathrm{sSL}}$ across the water column during one semidiurnal tidal cycle. The $u$ component was calculated by the decomposition of velocity according to equation 3 (Miranda et al., 2012):

$$
\mathrm{u}=\mathrm{Vel} \cdot \operatorname{Cos} \theta
$$

Where Vel is the collected current magnitude and $\theta$ is the final argument for velocity vector decomposition, given by:

$$
\theta=90^{\circ}-(d d \pm D) \pm \gamma
$$

Where $d d$ is the velocity direction, $D$ is the local magnetic declination and $\gamma$ is the rotation required for the Ox axis to be oriented longitudinally to the estuary.

\section{RESULTS}

\section{VERTICAL VELOCITY PROFILES}

The results of the residual time profiles of the velocity field (Figure 2 ) indicate that there was no current inversion on the right margin (RM) in either season, with a maximum of $0.475 \mathrm{~m} \mathrm{~s}^{-1}$ for the dry season and $0.519 \mathrm{~m} \mathrm{~s}^{-1}$ for the wet season. The minimum values were $0.097 \mathrm{~m} \mathrm{~s}^{-1}$ in the dry season and $0.050 \mathrm{~m} \mathrm{~s}^{-1}$ in the wet season.

On the left margin (LM), the distribution pattern was similar to that of the RM during the dry season, with a maximum of $0.385 \mathrm{~m} \mathrm{~s}^{-1}$ and a minimum of $0.112 \mathrm{~m}$ $\mathrm{s}^{-1}$ and no current inversion (Figure 2). During the wet season, however the vertical profile indicated the inversion of approximately $30 \%$ of the water column, with values ranging from $0.043 \mathrm{~m} \mathrm{~s}^{-1}$ to $-0.858 \mathrm{~m} \mathrm{~s}^{-1}$.

\section{SUSPENDED SOLID CONCENTRATIONS AND TRANSPORT}

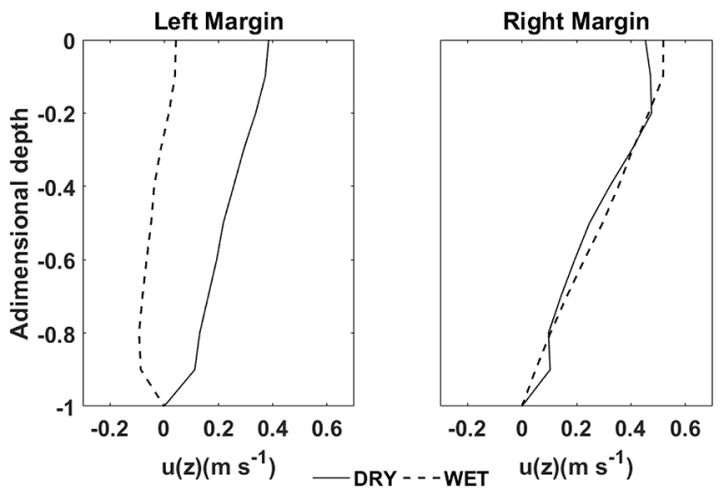

Figure 2. Vertical residual profiles of $u$ velocity component for the dry (solid line) and wet seasons (dashed line), on the two margins of the Pará River Estuary.

The temporal and spatial $\mathrm{T}_{\text {SSL }}$ and $\mathrm{C}_{\text {SSL }}$ estimates indicated considerable differences in distribution patterns between both seasons and margins (Figure 3). The highest $C_{\text {sSL }}$ concentration was recorded on the right margin (more than $300 \mathrm{mg} \mathrm{L}^{-1}$ ) in the dry season, whereas on the left margin, the value was only approximately $7 \mathrm{mg} \mathrm{L}^{-1}$. During the wet season, the highest value was approximately $250 \mathrm{mg} \mathrm{L}^{-1}$ on the $\mathrm{LM}$ and $7 \mathrm{mg} \mathrm{L}^{-1}$ on the left margin.

The suspended solid exportation $\left(\mathrm{T}_{\text {sSL }}\right)$ was also higher on the RM than the $L M$, reaching a maximum of $0.9229 \mathrm{~kg} \mathrm{~m}^{-1} \mathrm{~s}^{-1}$ during the dry season and $0.6650 \mathrm{~kg}$ $\mathrm{m}^{-1} \mathrm{~s}^{-1}$ in the wet season. However, the estimates of the importation of SSL into the PRE was essentially the same for the two margins, with maximum values of around $-0.6450 \mathrm{~kg} \mathrm{~m}^{-1} \mathrm{~s}^{-1}$ during dry season and approximately $-0.2040 \mathrm{~kg} \mathrm{~m}^{-1} \mathrm{~s}^{-1}$ during wet season (Figure 3).

The temporal variation in the residual profiles for the two seasons (Figure 4) revealed vertical gradients in both the $\mathrm{C}_{S S L}$ and the $\mathrm{T}_{\mathrm{SSL}}$. On the left margin, the increase in the $C_{\text {SSL }}$ was evident across $80 \%$ of the water column, reaching values close to $100 \mathrm{mg} \mathrm{L}^{-1}$ in both seasons. On the right margin, the findings were similar in the wet season, but in the dry season, the $\mathrm{C}_{\text {SSL }}$ values increased strongly across $80 \%$ of the water column, with values exceeding $350 \mathrm{mgL}^{-1}$ close to the bottom ( $100 \%$ of the water column). 

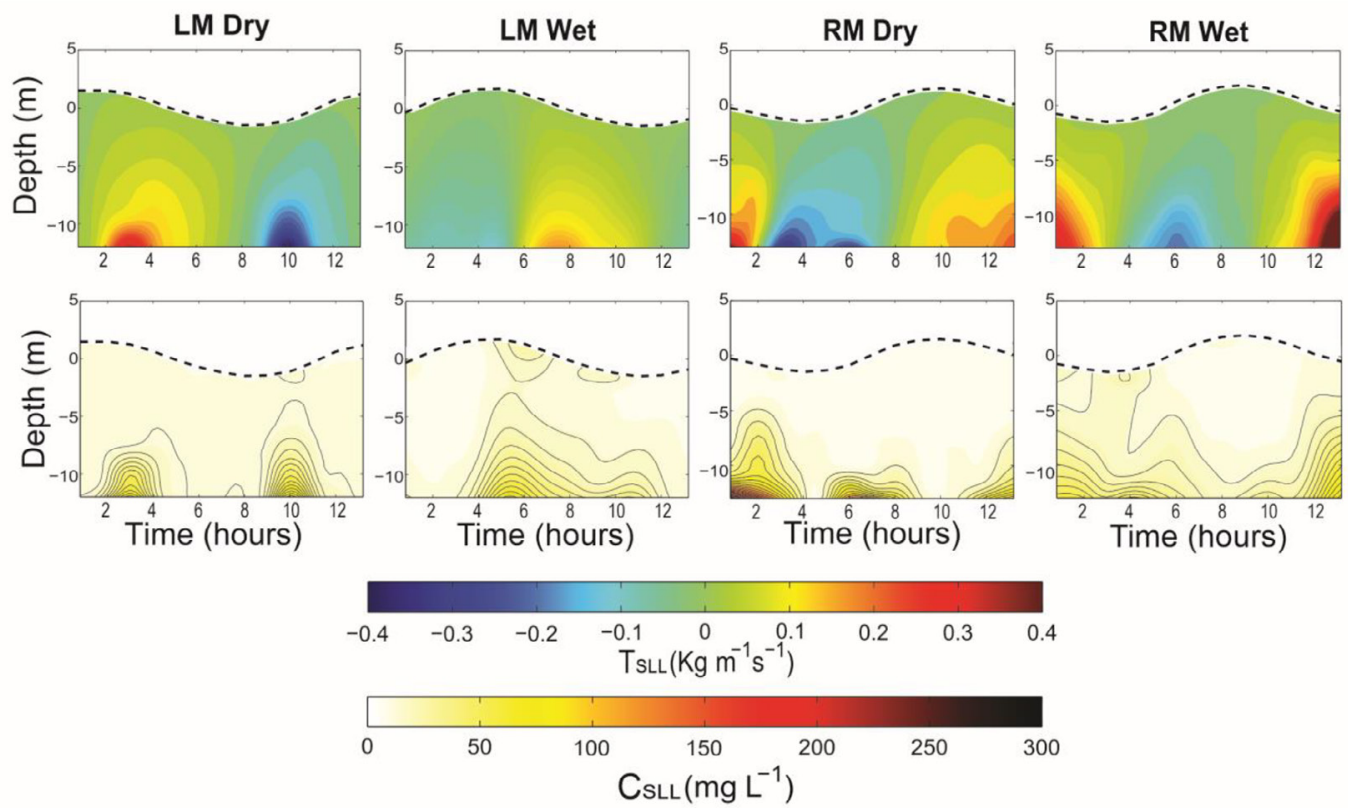

Figure 3. Variation in the vertical structure of the $C_{S S L}$ and $T_{S S L}$ values recorded over a semidiurnal tidal cycle on the two margins (LM, RM) of the Pará River Estuary.
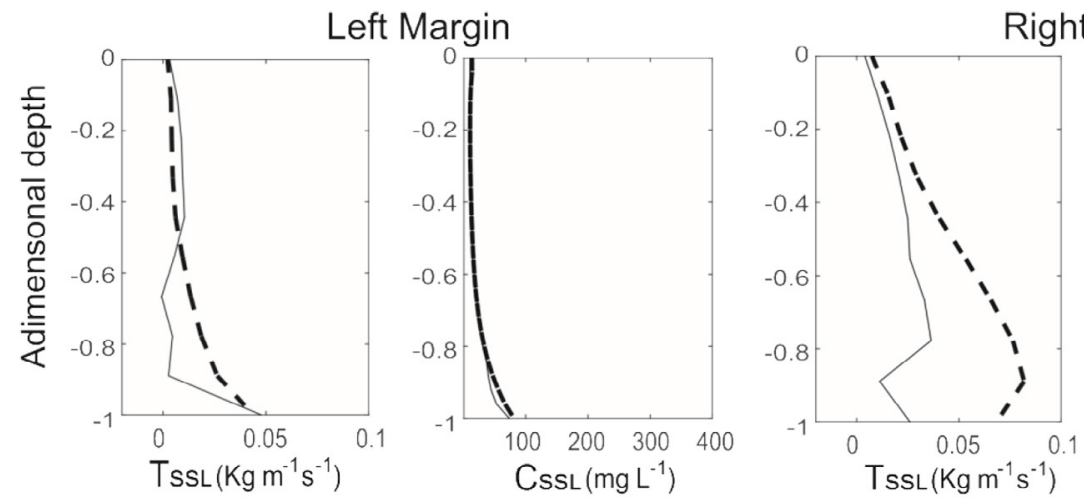

- Dry $=-\boldsymbol{- W e t}$

Figure 4. Vertical residual profiles of the $\mathrm{C}_{\mathrm{SSL}}$ and $\mathrm{T}_{\mathrm{SSL}}$ for the dry season (solid lines) and the rainy season (dashed lines), on each margin of the Pará River Estuary.

As in the vertical gradients of the $u$ component, the direction of the propagation of the residual $\mathrm{T}_{S \mathrm{SL}}$ temporal profiles (Figure 2) also did not invert, that is, there was no $T_{\text {SSL }}$ in the upstream direction of the PRE in either season. Shifts were also observed in the vertical $\mathrm{T}_{\text {SSL }}$ gradients across approximately $80-90 \%$ of the water column.

\section{DISCUSSION}

The $\mathrm{C}_{\text {SSL }}$ and $\mathrm{T}_{\text {SSL }}$ values varied clearly with the tidal oscillation, with maximum values being similar on the slack high tide and the low tide. The differences in the $\mathrm{T}_{\text {SSL }}$ values between the two margins (RM and LM) may be related to a number of different factors, including the variation in the $u$ component of the velocity.

The longitudinal component of the velocity vector $(u)$ varied between the margins of the PRE, with the modulus of the $u$ values recorded on the RM being larger than those recorded on the LM. The residual values recorded on both margins were also prevalent towards the mouth of the estuary $(+u)$. 
There a sharp increase in the $\mathrm{T}_{\text {SSL }}$ on the RM at the beginning of the wet season, although the balance between import $\left(-\mathrm{T}_{\text {SSL }} \mathrm{Kg} \mathrm{m}^{-1} \mathrm{~s}^{-1}\right)$ and export values $\left(+\mathrm{T}_{\text {SSL }}\right.$ $\left.\mathrm{Kg} \mathrm{m}^{-1} \mathrm{~s}^{-1}\right)$ indicated a net export of suspended solids to the adjacent ocean in both seasons. The LM also presented the same $\mathrm{T}_{\text {SSL }}$ export pattern in both campaigns, although its values were lower than those of the RM, and there was a slight difference between seasons (Figure 3).

Using a box model Prestes et al. (2020) estimated the flow of the PRE as approximately $2 \times 10^{4} \mathrm{~m}^{3} \mathrm{~s}^{-1}$, and also discovered that the principal tributary contributing to this flow is the Tocantins River, which has a sedimentary load of 18 million tons per year (Latrubesse and Stevaux, 2002). The author also estimated that $5 \%$ of the mean annual discharge of the Amazon River flows into the Pará River system through the Breves Strait, which is consistent with Callède et al. (2010) estimate of around $6 \%$.

The probable origins of the suspended solids transported to the PRE thus include its two principal tributaries, the Tocantins and Pará Rivers. The Tocantins is the principal source of freshwater input to the estuary, while the Pará River receives part of the discharge of the Amazon through the Breves Strait. The increase in the $\mathrm{C}_{\mathrm{SSL}}$ during the wet season can also be accounted for by the seasonal shift in the suspended sediment export routes, with the PRE becoming the sole destination during the wet season. As the PRE has no source of its own, it is difficult to define the exact origin of the $T_{\text {SSL }}$ into this system, given that it receives input from a number of different tributaries (Callède et al., 2010).

Both Lentz and Limerbuner (1995) and Mascarenhas et al. (2016) observed seasonal variation in the eastern sector of the Amazon River plume, near the mouth of the PRE, and concluded that, even in this area, the Amazon River exerts an influence due to the enormous extension of its plume. Tidal penetration is also one of the principal forces transporting and regulating the suspended solids dynamics in estuarine environments, in particular, macrotidal ones. Given the reach of the PRE, onto the Amazon Continental Shelf and adjacent ocean, the interaction of its plumes with that of the Amazon may determine the final destination of its suspended solids.

The lutocline was estimated based on the vertical structure of the $\mathrm{C}_{\mathrm{SSL}}\left(\left\langle\mathrm{C}_{\mathrm{SSL}}\right\rangle\right)$ residuals. The lutocline is the interface between clear water on the top and a fluid-mud mixture underneath, characterized by a strong gradient in sediment concentrations (Ross and Metha, 1989; Wolanski et al., 1989). Typically, there is a turbulent flow above the lutocline, while a viscous flow predominates below, where higher sediment concentrations are observed, including the presence of fluid mud, in certain cases (Ross and Metha, 1989; Vinzon and Metha, 2001).

The principal analytical parameter is the thickness of the lutocline, which was greater on the RM than the LM of the PRE in dry period, characterized by a strongly increase in $\mathrm{C}_{\text {SSL }}$ from $80 \%$ of water column. Two studies in the Amazon have shown extensive areas of fluid mud on both the inner and outer continental shelf, and the presence of a lutocline in the area of the mouth of the Amazon River (Gabioux et al., 2005; Kineke et al., 1996). However, no major vertical stratification of suspended sediments was identified in some areas to the west of the mouth of the Amazon, which was attributed to the strong mixing processes found this sector, which inhibit the formation of fluid mud or a lutocline (Gabioux et al., 2005; Kineke et al., 1996).

\section{ESTIMATES OF LATERAL DIFFERENTIATION IN SUSPENDED SOLID TRANSPORT}

A linear regression between suspended solid concentration in the near-bottom layers $\left(C_{S S L(B)}\right)$ and mean values across the water column, as described by Nichols (1984), was used to investigate the importance of the resuspension of solids deposited in the substrate for the control of the vertical distribution of the suspended solids. This analysis indicated that the suspended solids present on the RM and the LM may derive from the resuspension of the material deposited in the riverbed, although this material does not have an exact source. The $r^{2}$ were high (>50\%), which indicates that the suspended solids present in the water column were derived from the resuspension of the material present in the substrate.

Overall, the two margins presented different seasonal patterns. On the RM, the $r^{2}$ values increased during the rainy season, whereas on the LM the $r^{2}$ decreased. The values were higher on the $L M$, however, peaking during the dry season, with an $\mathrm{r}^{2}$ value of approximately $90 \%$ (Figure 5 ).

Lee et al. (2013) calculated the non-dimensional $R i$ number and suspended sediment concentration (SSC) for the Han estuary, in the east of the macrotidedominated Yellow Sea. These authors observed that the level of vertical stratification varied in accordance with the Ri number, and that the closer Ri was to 0.25 , 

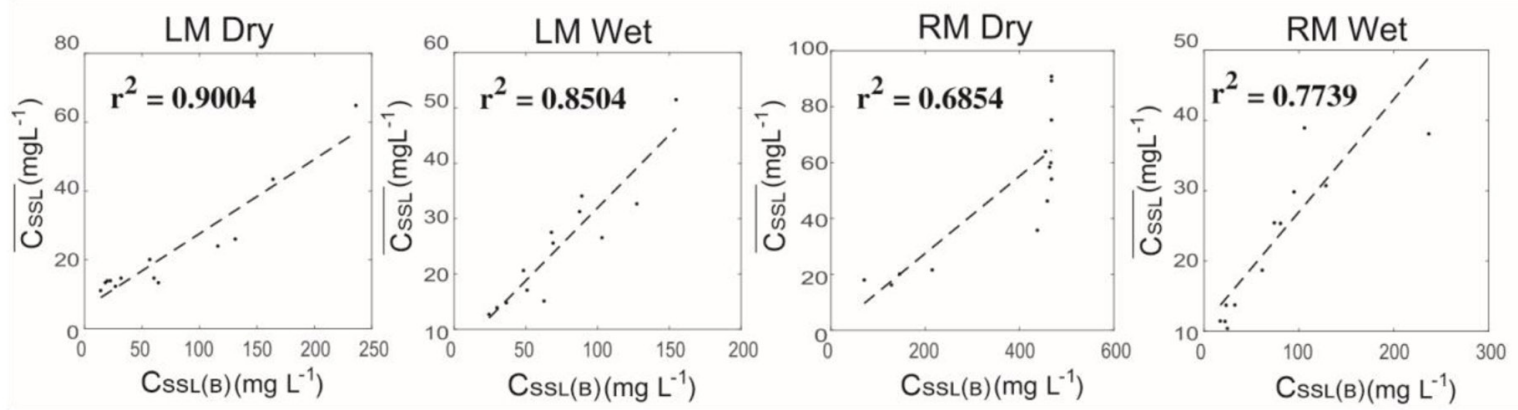

Figure 5. Linear regression between the $\mathrm{C}_{\mathrm{SSL}(\mathrm{B})}$ and $\left(\overline{\mathrm{C}_{\mathrm{SSL}}}\right)$, and corresponding $\mathrm{r}^{2}$ values, on both margins (RM and $\left.L M\right)$ in both seasons.

the more the SSC in the water column tended to be mixed (i.e., the stratification level was lower), similar to the pattern observed in the PRE.

The differences found between the two points in the present study thus indicated that the main source of the $\mathrm{C}_{\mathrm{SSL}}$ transported to the LM of the estuary is the material deposited on the substrate through the resuspension process. On the RM, by contrast, part of the suspended solids present in the water column derive from sources external to the sampling point.

One other factor that must be taken into consideration is the nature of the estuary bottom and the influence of its hydrodynamics. Corrêa (2005) classified the hydrodynamics of the Mixing Zone of the PRE based on a Pejrup diagram, and concluded that the left margin, where the bottom sediment granulometry varies from intermediate to fine sand, is subject to the influence of a high energy hydrodynamic regime. By contrast, the sedimentation on the right margin ranges from coarse to fine silt, which is deposited typically in lower-energy regimes.

This suggests that the lack of vertical stratification on the LM is due to high hydrodynamics, as indicated by the sandy nature of the substrate, which tends to be resuspended. The RM has a more stable hydrodynamic regime with a predominance of silty sedimentation. Given the highly turbulent conditions found on the left margin of the PRE, where intense vertical mixing occurs by advection, the results of the present study indicate that there is intensive resuspension of the material deposited on or near the substrate on this margin.

\section{ACKNOWLEDGMENTS}

This study is a result of the projects PróAmazônia (Notice $n^{\circ} 047 / 2012$ - Process $n^{\circ}$
23038.007835/2012-19) and Rede de Hidrologia Amazônica (RHIA - financed by FINEP/CT-HIDRO). The authors would like to thank the Federal University of Pará (UFPA) and the Laboratório de Pesquisa em Monitoramento Ambiental Marinho (LAPMAR - Laboratory of Marine Environmental Monitoring Research), for providing the structure and the technical and scientific support throughout this study.

\section{AUTHOR CONTRIBUTIONS}

A.G.C.: Conceptualization; Data curation; Investigation; Methodology; Visualization; Writing original draft; Writing - review \& editing;

Y.O.P.: Conceptualization; Investigation; Methodology; Writing - review \& editing;

M.R.: Conceptualization; Funding acquisition; Project administration; Resources; Supervision Visualization; Writing - review \& editing.

\section{REFERENCES}

ALLEN, G. P., SALOMON, J. C., BASSOULLET, P., DU PENHOAT, Y. \& DE GRANDPRÉ, C. 1980. Effects of tides on mixing and suspended sediment transport in macrotidal estuaries. Sedimentary Geology, 26(1-3), 69-90.

AVELINE, L. C. 1980. Fauna dos manguezais brasileiros. Revista Brasileira de Geografia, 42(4), 786-821.

BAUMGARTEN, M. G. Z., ROCHA, J. M. B. \& NIENCHESKI, L. F. H. 2010. Manual de análises em Oceanografia Química, Rio Grande: Editora da Universidade Federal do Rio Grande.

BEARDSLEY, R. C., CANDELA, J., LIMEBURNER, R., GEYER, W. R., LENTZ, S. J., BELMIRO, M. C., CACCHIONE, D. \& CARNEIRO, N. 1995. The M2 tide on the Amazon shelf. Journal of Geophysical Research, 100(2), 2283-2319.

CALLÈDE, J., COCHONNEAU, G., RONCHAIL, J., ALVEZ, F. V., GUYOT, J. L., GUIMARES, V. S. \& DE OLIVEIRA, E. 2010. Les apports en eau de l"Amazone a l'ocean Atlantique. Journal of Water Science, 23(2), 247-273.

CAMERON, W. M. \& PRITCHARD, D. W. 1963. Estuaries. In: HILL, M. N. (ed). The sea: ideas and observation on progress in the study of the seas. New York: John Wiley and Sons. 
CORRÊA, I. C. S. 2005. Aplicação do diagrama de Pejrup na interpretação da sedimentação e da dinâmica do Estuário da Baía do Marajó-PA. Pesquisa em Geociências, 32(2), 109-118.

DYER, K. R. 1994. Estuarine sediment transport and deposition. In: PYE, K. (ed). Sediment transport and depositions processes. United Kingdom: Blackwell Scientific Publications.

DYER, K. R. 1997. Estuaries: a physical introduction. New York: John Wiley \& Sons.

EL-ROBRINI, M., SILVA, M. A. M. A., SOUZA FILHO, P. W. M., ELROBRINI, M. H. S., SILVA JÚNIOR, O. G. \& FRANÇA, C. F. 2006. Pará. In: MUEHE, D. (ed). Erosão e Progradação do Litoral Brasileiro. Brasília: Instituto Brasileiro do Meio Ambiente e dos Recursos Naturais Renováveis.

EMERY, W. J. \& THOMSON, R. E. 2014. Date analysis methods in physical oceanography. Poland: Newnes.

GABIOUX, M., VINZON, S. B. \& PAIVA, A. M. 2005. Tidal propagation over fluid mud layers on the Amazon shelf. Continental Shelf Research, 25(1), 113-125.

HANSEN, D. V. \& RATTRAY, M. J. 1966. New dimensions in estuary classification. Limnology and Oceanography, 11(3), 319-326.

HUNT, S., LEMCKERT, C. \& SCHACHT, C. 2000. Suspended sediment distribution within a partially mixed subtropical estuary. Journal of Coastal Research, SI(34), 382-387.

ISAAC, V. J., SANTO, R. V. E., BENTES, B., FRÉDOU, F. L., MOURAO, K. R. M., \& FRÉDOU, T. 2009. An interdisciplinary evaluation of fishery production systems off the state of Pará in North Brazil. Journal of Applied Ichthyology, 25(3), 244-255.

KINEKE, G. C., STERNBERG, R. W., TROWBRIDGE, J. H. \& GEYER, W. R. 1996. Fluid mud processes on the Amazon continental shelf. Continental Shelf Research, 16(5-6), 667-696.

KJERFVE, B. 1987. Estuarine geomorphology and physical oceanography. In: DAY, J. W., HALL, C. A. S., KEMP, W. M. \& YÁÑEZ-ARANCIBIA, A. (eds.). Estuarine Ecology. New York: John Wiley \& Sons.

LATRUBESSE, E. M. \& STEVAUX, J. C. 2002. Geomorphology and environmental aspects of the Araguaia fluvial basin, Brazil. Zeitsshrift für Geomorphologie, 129(1), 109-127.

LEE, H. J., PARK, J. Y., LEE, S. H., LEE, J. M. \& KIM, T. K. 2013. Suspended sediment transport in a rock-bound, macrotidal estuary: Han Estuary, Eastern Yellow Sea. Journal of Coastal Research, 29(2), 358-371.

LENTZ, S. J. \& LIMERBUNER, R. 1995. The Amazon River Plume during AMASSEDS: spatial characteristics and salinity variability. Journal of Geophysical Research, 100(C2), 23552375.

MASCARENHAS, A. C. C., GOMES, G. S., LIMA, A. P.Y., SILVA, H. K. N., SANTANA, L. S., ROSÁRIO, R. P. \& ROLLNIC, M. 2016. Seasonal variations of the Amazon River plume with focus on the Eastern sector. Journal of Coastal Research, SI(75), 532-536.

MIRANDA, L. B., CASTRO, M. C. \& KJERFVE, B. 2012. Princípios de oceanografia de estuários. São Paulo: Editora da Universidade de São Paulo.

MORAES, B. C., COSTA, J. M. N., COSTA, A. C. L. \& COSTA, M. H. 2005. Variação espacial e temporal da precipitação no Estado do Pará. Acta Amazôniza, 35(2), 207-214.

MOURÃO, K. R. M., SOUSA FILHO, P. W. M., ALVES, P. J. O. \& FRÉDOU, F. L. 2014. Priority areas for the conservation of the fish fauna of the Amazon Estuary in Brazil: A multicriteria approach. Ocean \& Coastal Management, 100(1), 116-127.
NICHOLS, M. M. 1984. Effects of fine sediment resuspension in estuaries. In: BARBER, R. T., MOOERS, C. N. K. \& BOWMAN, M, J. (eds.). Estuarine Cohesive Sediment Dynamics. Berlin: Springer-Verlag.

PAPHITIS, D. \& COLLINS, M. B. 2005. Sediment resuspension events within the (microtidal) coastal waters of Thermaikos Gulf, Northern Greece. Continental Shelf Research, 25(1), 2350-2365.

POSTMA, H. 1967. Sediment transport and sedimentation in the estuarine environment. In: LAUFF, G. H. (ed). Estuaries. Washington: American Association for Advanced of Science.

PRESTES, Y. O., BORBA, T. A. C., DA SILVA, A. C. \& ROLLNIC, M. 2020. A discharge stationary model for the Pará-Amazon estuarine system. Journal of Hydrology: Regional Studies, 28, 100668.

PRITCHARD, D. W. 1967. What in an estuary: physical viewpoint. In: LAUFF, G. H. (ed.). Estuaries. Washington: American Association for the Advancement of Science.

ROSS, M. A. \& METHA, A. J. 1989. On the mechanics of lutoclines and fluid mud. Journal of Coastal Research, SI(5), 51-61.

SCHAEFFER-NOVELLI, Y., CINTRÓN-MOLERO, G., ADAIME, R. R., \& DE CAMARGO, T. M. 1990. Variability of mangrove ecosystems along the Brazilian coast. Estuaries, 13(2), 204-218.

SCHAEFFER-NOVELLI, Y., CINTRÓN-MOLERO, G., SOARES, M. L. G., \& DE ROSA, T. 2000. Brazilian mangroves. Aquatic Ecosystem Health \& Management, 3(4), 561-570.

SCHETTINI, C. A. F., DE ALMEIDA, D. C., SIEGLE, E. \& DE ALENCAR, A. C. B. 2010. A snapshot of suspended sediment and fluid mud ocurrence in a mixed-energy embayment, Tijucas Bay, Brazil. Geo-Marine letters, 30(1), 47-62.

SCHETTINI, C. A. F., PEREIRA, M. D., SIEGLE, E., MIRANDA, L. B., SILVA, M. P. 2013. Residual fluxes of suspended sediment in a tidally dominated tropical estuary. Continental Shelf Research, 70, 27-35.

SCHUBEL, J. R. 1971. Tidal variation of the size distribution of suspended sediment at a station in the Chesepeake Bay turbidity maximum. Netherlands Journal of Sea Research, 5(2), 252-266.

SAENGER, P., HEGERL, E. J. \& DAVIE, J. D. S. 1983. Global status of mangrove ecosystems. The Environmentalist, 3, 1-81.

SIEGLE, E., SCHETTINI, C. A. F., KLEIN, A. H. F. \& TOLDO JUNIOR, E. E. 2009. Hydrodynamics and suspended sediment transport in the Camboriú estuary - Brazil: pre jetty conditions. Brazilian Journal Oceanography, 57(2), 123-135.

UNCLES, R. J., STEPHENS, J. A. \& SMITH, R. E. 2002. The dependence of estuaries turbidity on tidal intrusion length, tidal range and residence time. Continental shelf research, 22(11-13), 1835-1856.

UNCLES, R. J. \& MONISMITH, S. G. 2011. Water and fine-sediment circulation. Treatises on Estuarine and Coastal Science, 2, 1-8.

VINZON, S. B. \& MEHTA, A. J. 2001. Boundary layer effects due to suspended sediment in the Amazon River estuary. In: MCANALLY, W.H. \& MEHTA A. J. (eds.). Coastal and Estuarine Fine Sediment Processes. Amsterdam: Elsevier Science.

WINTERWERP, J. C. 2011. The physical analyses of muddy sedimentation processes. Treatises on Estuarine and Coastal Science, 2, 311-360.

WOLANSKI, E., ASAEDA, T., \& IMBERGER, J. 1989. Mixing across a lutocline. Limnology and Oceanography, 34(5), 931-938.

WOOD, P. A. 1977. Controls of variation in suspended sediment concentrations in the River Rother. Sedimentology, 24(3), 437-445. 